\title{
Synthesis and Evaluation of Unsaturated Alkyl Esters of 5-Aminolevulinic Acid as Precursors to Protoporphyrin IX
}

\author{
Choonsil Jo, Yun Ju Jo, Hyoung-Ryun Park, Jee-Bum Lee, ${ }^{\dagger}$ Yong-Hyun Kwon, ${ }^{\dagger}$ \\ Sunwoo Lee, Keun Ho Chun, ${ }^{*}$ and Jonghoon Oh* \\ Department of Chemistry, Chonnam National Lniversity, Gwangin 500-757, Korea. ${ }^{*}$ E-mail jnoh achonamackr \\ ${ }^{\dagger}$ Department of Dermatology, Chomam National Lniversity Hedical School, Gu'angit 501-757, Korea \\ -Department of Chemistry, Soongsil Chniersity, Seoul 156-743, Korea \\ Received October 31, 2006
}

Key Words : 5-Aminolevulinic acid (ALA). Unsaturated alkyl esters of ALA. Protoporphy rin IX (PpLX). Photodýnamic therapy (PDT). Fluorescence spectra of photosensitizer PpLX

5-Aminolevulinic acid (ALA). a non-fluorescent drug has been used as a precursor to the fluorescent photosensitizer protoporphyrin $\mathrm{XX}(\mathrm{PpIX})$ in photodynamic therapy (PDT) ${ }^{1-3}$ $\mathrm{Pp}[\mathrm{X}$ converts. under irradiation of visible light triplet oxygen ( $\left.{ }^{3} \mathrm{O}_{2}\right)$ to singlet oxy'gen $\left({ }^{\mathrm{l}} \mathrm{O}_{2}\right)$, which initiates the PDT causing the death of abnormal cells. Hence the efficient penetration of ALA into skin would result in increased accumulation of PpIX and better PDT. Specifically. the limited bioavailability of PpIX is due to hydrophilicity of ALA. To address this limitation of uptake and distribution of ALA. the drug has been converted into its esters to increase its lipophilic nature. ALA esters from saturated aliphatic alcohols of $\mathrm{C} 6-\mathrm{C} 8$ chain were, when applied to skin. found to increase the temporal amount of $\mathrm{PpLX}$ in tissue than ALA free acid. ${ }^{46}$ Methyl, hexyl. octyl, and other esters of ALA were synthesized and investigated as promising precursors to PplX in vitro and in wivo as well

However. there are only a limited number of synthetic methods and procedures for ALA esters available. Simple esters such as methyl and hexyl esters were prepared by heating ALA and thionyl chloride or hydrochloric acid in corresponding alcohols. Higher alkyl esters were prepared through three step reactions which include amino functional group protection. esterification and deprotection. ALA was treated with Boc anhydride and the resulting $\mathrm{N}$-protected ALA was converted to ester by DMAP. EDCI and alcohol. Acidic hydrolysis of the resulting N-Boc ester gave the ALA ester hydrochloride. ${ }^{7-9}$

As the importance of PDT increases. new efficient synthetic methodology for a variety of esters of ALA is necessary. Although synthesis and increased bioavailability of ALAesters from saturated hydrocarbon alcohols have been reported. esters of ALA with unsaturated alcohols have never been reported in the literature to the best of our knowledge. Thus our research interest was focused on the study of $\pi$-bond effects to bioavailability of the esters and developing a short and convenient. practically. one-pot procedure for ALA esters.

\section{Experimental Section}

Representative procedure. To a solution of DMF (3 drops) in thionyl chloride $(\mathrm{mL})$ was added ALA $\mathrm{HCl}(200$ mg. $1.19 \mathrm{mmol}$ ) at room temperature (rt). The resulting reaction mixture was stirred for $12 \mathrm{~h}$ and evaporated under reduced pressure to give reactive intermediate. To the residue was added 5-hexen-1-ol $(0.5 \mathrm{~mL})$ and stirred for $1.5 \mathrm{~h}$ at $\mathrm{rt}$ and evaporated under reduced pressure and purified silica gel column chromatography to give $265 \mathrm{mg}(89 \%)$ of 5 hexenyl 5-aminolevulinate hydrochloride as yellow oil. $\left(\mathrm{MeOH}: \mathrm{CH}_{2} \mathrm{Cl}_{2}, 1: 8\right) .89 \%$.

${ }^{l} \mathrm{H}$ NMR (300 MHz. DMSO-d6): $\delta 8.33$ (s. 3H). 5.85-5.71 (m. 1H) . 5.04-4.92 (m. 2H). $3.99(\mathrm{t} . J=6.5 \mathrm{~Hz} .2 \mathrm{H}) .3 .93(\mathrm{~s}$. $2 \mathrm{H}) .2 .78(\mathrm{t} . J=6.6 \mathrm{~Hz}, 2 \mathrm{H}) .2 .53(\mathrm{t} . J=6.6 \mathrm{~Hz}, 2 \mathrm{H}) .2 .02$ (q. $J=7 \mathrm{~Hz}, 2 \mathrm{H}$ ), 1.56 (quintet. $J=6.7 \mathrm{~Hz}, 2 \mathrm{H}$ ), 1.38 (quintet. $J=5.1 \mathrm{~Hz} .2 \mathrm{H}$ ): ${ }^{13} \mathrm{C}$ NMR (75 MHz. DMSO-d 6 ): $\delta$ $202.66,172.05,138.41,115.02,63.92,46.52,34.26,32.69$. $27.56,27.08 .24 .55$.

MTT viability assay. A431 cells. an epidermal squamous cell carcinoma cell line. obtained from Korean cell line bank (KCLB No. 80005), were seeded into 96 well plate. and treated with ALA and ALA esters in variable concentrations for 24 hours to check cellular toxicity of ALA unsaturated esters. Colorimetric (MTT) kit for cell survival and proliferation (CHEMICON International Inc.. USA) was used following manufacturer's protocol ${ }^{1 / 1}$ Briefly. MTT (3-[4.5dimethylthiazol-2-yl]-2.5-dipheny ltetrazoliumbromide) solution $100 \mu \mathrm{L}$ was added to each well in a concentration of $0.5 \mathrm{mg} / \mathrm{mL}$, and plates were incubated at $37^{\circ} \mathrm{C}$ for 2 hours. The resulting formazan cristals were dissolved by the addition of $100 \mu \mathrm{L}$ of DMSO (dimethylsulfoxide) and absorbance was read at $570 \mathrm{~nm}$ in ELISA reader (Molecular Device. USA). The results are shown in Figure 1.

Measurement of cellular PpLX synthesis. UV/Vis absorption spectra were taken using Uvikon (model 943) spectrophotometer with a $1.0 \mathrm{~nm}$ spectral bandwidth. The steady-state fluorescence emission spectra were obtained on a Varian Cary Eclipse spectrofluorometer with $10 \mathrm{~nm}$ slits at room temperature. The absorption spectrum of $2.8 \times 10^{-5} \mathrm{M}$ of $\mathrm{PpIX}$ in methanol-water mixture solution $(50 \% \mathrm{v} / \mathrm{v})$ containing $1 \mathrm{M} \mathrm{HClO}_{4}$ revealed very sharp absorption maximum peak at the $408 \mathrm{~nm}$ and the molar extinction coefficient of the compound was determined to be $2.7 \times 10^{4} \mathrm{M}^{-1} \mathrm{~cm}^{-1}$ in the solvent. 


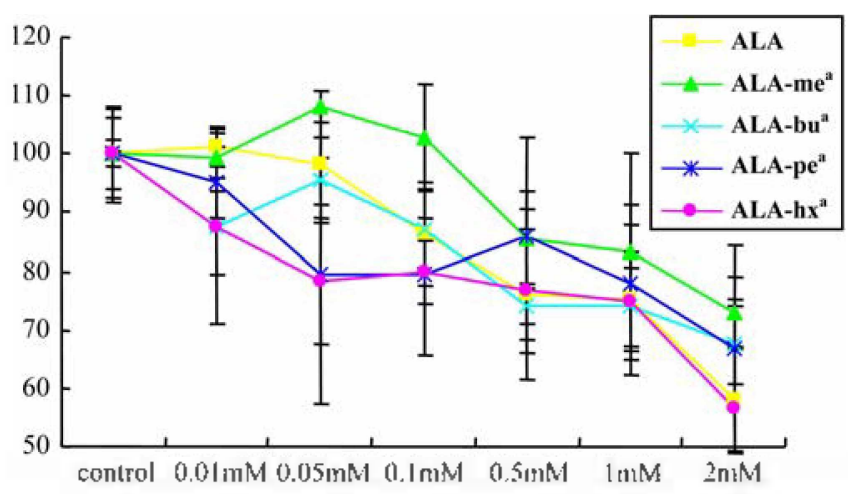

Figure 1. The cell survival of $\wedge 431$ cell and cytotoxicity of $\wedge I \wedge$ and its unsaturated alkyl esters. " $\Lambda \mathrm{L} \Lambda-\mathrm{me}: \Lambda \mathrm{L} \Lambda$ methyl ester. ALA-bu: 3-butenyl 5-aminolevulinate hodrochloride (entry 6 in Table 1). AlA-pe: 4-pentenyl 5-aminolevulinate hydrochloride (enty 7). AIA-hx: 5-hexelyy 5-aminolevulinate hydrochloride (entry 8). MT'T assay was performed in triplicate and cell survival Has expressed as percentage.

A431 cells were subcultured in Dulbecco's modified Eagle Medium (Bio-whittaker, Walkersville Inc.. MD, USA) containing $10 \%$ fetal bovine serum (FBS), 100 units $/ \mathrm{mL}$ penicillin and $10 \mathrm{ug} / \mathrm{mL}$ streptomycin. The cells were grown and incubated in $75 \mathrm{~cm}^{2}$ flask (Falcon. NJ. USA) at $37^{\circ} \mathrm{C}$ in a humidified atmosphere containing $5 \% \mathrm{CO}_{2}$, and subcultured two times per week. Approximately $1 \times 10^{6}$ cells were seeded into $10 \mathrm{~cm}^{2}$ dishes (Falcon), and cultured for 48 hours. Subsequently, the cells were washed twice with serum-free culture medium, and further incubated in serumfree culture medium containing different concentration of ALA and its esters for 4 hours without exposure to light. The cells were then washed twice with PBS and brought into a solution containing $1 \mathrm{M} \mathrm{HClO}_{4}$ in $50 \%$ methanol by scraping with a cell scraper. ${ }^{+}$After 5 min incubation, the cell debris was removed by centrifugation $(13,000 \mathrm{rpm} / \mathrm{min}, 10$ min), and the supernatant was collected into new tubes without light exposure. The fluorescence spectra of $\mathrm{PplX}$ of

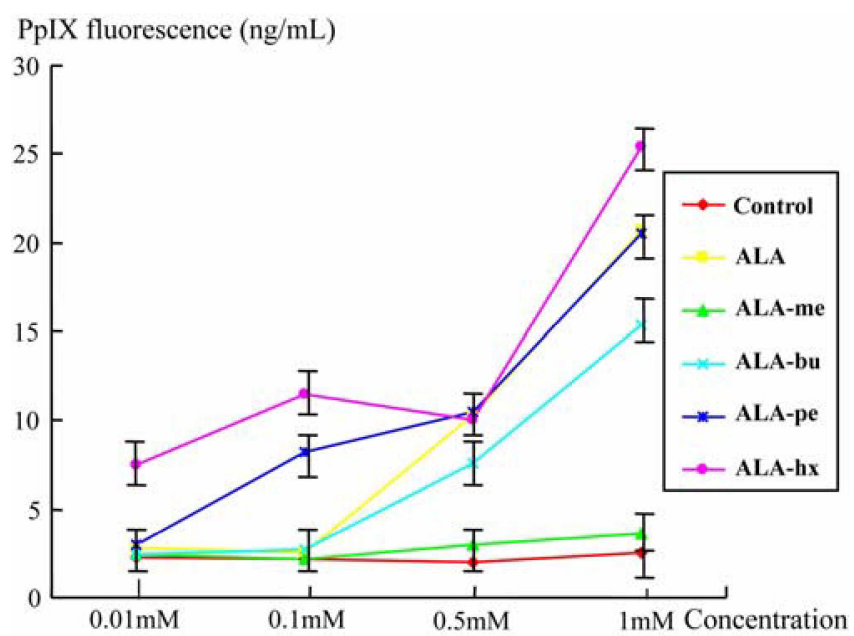

Figure 2. PplX synthesis in A431 cell from unsaturated alkyl esters of $\mathrm{Al}, \mathrm{A}$ and $\mathrm{Al} . \mathrm{A}$. sample at the $408 \mathrm{~nm}$ as the excitation wavelength were measured in the range of $573 \mathrm{~nm}$ to $800 \mathrm{~nm}$. The quantity of PpIX synthesized in A 431 cell was determined from the area under the emission curve of fluorescence spectra and the results are shown in Figure 2 .

\section{Results and Discussion}

Vilsmeier-type reactions were widely used for the preparation of reactive intermediate acid chloride from a variety of carboxylic acids for further elaborations." Among many modified procedures, one of the mildest and most efficient way of generating acid chloride is to use excess thionyl chloride with catalytic amount of N.N-dimethylformamide (DMF). ${ }^{12}$

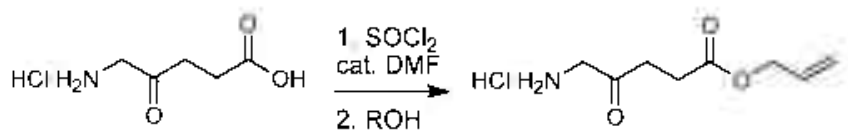

Hence, we decided to apply this method to synthesize ALA esters. To verify the efficiency of this method, saturated long chain alkyl esters, which are reported to literature. were prepared, and the isolated yields were compared with the literature (entries I-4 of Table 1). It is found that saturated alkyl esters could be prepared in good yields without protecting and deprotecting amino group.

With various unsaturated alcohols such as such as allylic alcohols, homoallylic alcohols and alcohols with trans and $c i s$ double bond, ALA was conveniently converted into corresponding esters in excellent to moderate yields using only thionyl chloride and catalytic DMF in practically onepot reaction (entries 5-12 in Table 1 ).

It is noteworthy that our method for ALA esters, which is very simple and popular, is very convenient and effective compared to the literature procedure for long saturated alkyl esters which needed anino group protection and deprotection.

MTT viability assay. Cellular toxicity of ALA unsaturated esters was investigated by measuring cell survival using A431 cells, an epidermal squamous cell carcinoma cell line, obtained from Korean cell line bank (KCLB No. 80005). MT"' (3-[4,5-dimethylthiazol-2-yl]-2.5-diphenyltetrazoliumbromide) solution $100 \mu \mathrm{L}$ was added to each well, ${ }^{10}$ and absorbance of the resulting formazan crystals, after dissolving by the addition of $100, \mu \mathrm{L}$ of DMSO (dimethylsulfoxide), was read at $570 \mathrm{~nm}$ in ELISA reader (Molecular Device, USA). The percentage of cell survival was calculated from the absorbance ratio between treated well and control well. MIT' assay was performed in triplicate and the results are shown in Figure 1. In dilute concentrations $(0.01-0.1 \mathrm{mM})$ there is a slight decrease in cell survival in ALA unsaturated esters well compared to ALA and ALA-me, however, at higher concentrations (0.5-2 mM) ALA unsaturated esters are not so toxic as ALA and ALAme.

Measurement of cellular PpIX synthesis. After A431 
Table 1. ALA Esters Synthesized

entry

${ }^{a}$ yields reported in Ref. 8 are $83 \%, 74 \%, 70 \%$, and not reported, respectively.

cells were subcultured in Dulbecco's modified tagle Medium. incubated in $75 \mathrm{~cm}^{2}$ flask (Falcon. NJ, USA) at $37{ }^{\circ} \mathrm{C}$ in a humidified atmosphere containing $5 \% \mathrm{CO}_{2}$, and subcultured two times per week, approximately $1 \times 10^{6}$ cells were seeded into $10 \mathrm{~cm}^{2}$ dishes (Falcon), and cultured for 48 hours and washed twice with serum-free culture medium. The cells were further incubated in serum-free culture medium containing different concentration of ALA and its esters for 4 hours without exposure to light. "The fluorescence spectra of PplX of the cells, after appropriate treatment, at the $408 \mathrm{~nm}$ as the excitation wavelength were measured in the range of $573 \mathrm{~nm}$ to $800 \mathrm{~nm}$. The quantity of PplX synthesized in A 431 cell was determined from the area under the emission curve of fluorescence spectra and the results were showed in Figure 2.

ALA-me and butenyl ester (ALA-bu) show less production of PplX in A 431 cell than ALA even though the lipophilicity is increased after etherification. Gaullier ${ }^{+}$of al. reported similar results that ALA methyl ester produced less PplX than ALA in WiDr. NHIK 3025, and V79 cells.

Hexenyl ester (ALA-hx) increased the P'plX accumulation in A431 cell compared to ALA and ALA-me in broad range of concentrations. Pentenyl ester shows the similar results to ALA-hx. Based on M'Il assay on A 431 cell, vide ante. ALA -hx and ALA-pe are not more toxic than ALA above $0.5 \mathrm{mM}$ concentration. Even though experimentations for toxicity of esters and accumulation of PpLX were performed only on A431 cell, these results suggest that unsaturated alkyl ester ALA-hx has slightly enhanced cellular uptake and is readily hydrolyzed to get into the hem biosynthetic pathway to produce photosensitizer P'plX on cells. Hence. we propose ALA-hx would be an alternative photosensitizer for PD[ using PplX.

In conclusion, a convenient and efficient one-pot method for synthesis of unsaturated alkyl esters of ALA in good yields has been developed, and this methodology can be suitable for large scale synthesis. M'"] viability assay showed the absence of severe cytotoxicity of the alcohols released intracellularly from the synthesized esters and the fluorescence spectral measurement of J'plX produced in A43I cell confirms that the enhanced cellular uptake and rapid hydrolysis of unsaturated alkyl esters of ALA to ALA and production of photosensitizer $\mathrm{P} p \mathrm{p}$ X.

Acknowledgements. This work was supported by grant No. R[104-03-03 from the Regional Technology Innovation Program of the Ministry of Commerce. Industry and Energy (MOCIE). C. J. thanks the Seoul Science Fellowship Program (Seoul City Hall).

Supporting Information: The table of cell survival of A431 cell with ALA and its unsaturated alkyl esters. ' $\mathrm{H}$. and ${ }^{\text {"C }} \mathrm{C}$ NMR spectra of unsaturated alkyl esters of ALA are available on request to the corresponding author; jnoh (àchonnam.ac.kr, (fax)-82-62-530-3389.

\section{References}

1. Doughery. T. 1.: Gomer. C. J.: Henderson. B. W.: Jori. G: Kessel. 
D.: Korbelik. M.: Moan. J.: Peng. Q. J. Natl Cancer Inst. 1998. 90. 889-905.

2. Kentdy. J. C.: Pottier. R. H. J. Photochen. Phototiol. B: Biol. 1992. 14.275-292.

3. Collaud. S.: Juzeniene, A.: Moan. I.: Lange N. Cur. Hed. Chem.Anti-tancer f fgents 2004 f, $301-316$.

4. Gaullier. I.-M.: Berg. K.: Peng. Q.: Anllilt. H.: Selbo. P. K.: Ma, L.-W.: Moan. J. Cancer Res. 1997.57, 1481-1486.

5. Gerscher. S.: Connelly. J. P: Griffiths. J.: Brown. S. B.: MacRobert. A. J.: Wong. G.: Rhodes. L. E. Photochent Photohiol 2000. 72. $569-574$.

6. Lopez. R. F. V: Lange, N.: Guy, R: Bentley, M. V. L. B. Ads.
Drug Del. Rev. 2004, 56. 77-94.

7. Brunt1er. H.: Hausmant1. F.: Kmuechel. R. Photochem. Photobiol. 2003. $78.481-486$.

8. Takeya. H. Jpn. Kok ai Tokkvo Koho. TP4009360. 1992.

9. Berger. Y: Greppi, A.: Siri. O.: Neier, R: Juillerat-Jeanneret, L. d. 1led. Chem $2000,+3,4738-4746$.

10. Denizot, F; Lang, R. J. Immumol Hethods $1986,89,271-277$

11. Marson. C. M.: Giles. P. R. Sinthesis Using Tilsnteier Reagents: CRC Press: Boca Raton. 1994.

12. Huang. F. C.: Shoupe. T. S.: Lin. C. J.: Lee. T. D.: Chan. W. K.: Tan. J.: Schnapper, M.: Sul, J. T:; Gordon, R. J.: Sonnino, P. A. d. lied. Chem. 1989, 32, 1836-1842. 